\title{
Krónikus jobb koronária-elzáródás megnyitása homokoronáriás kollaterálison keresztüli retrográd megközelítéssel
}

\author{
Komócsi András', Pintér Tünde1, Kittka Bálint', Horváth Iván', Ili Renáta', \\ Katona András², Ungi Imre ${ }^{2}$
}

${ }^{1}$ Pécsi Tudományegyetem, Klinikai Központ, Szívgyógyászati Klinika, Pécs

${ }^{2}$ Szegedi Tudományegyetem, Általános Orvosi Kar, II. sz. Belgyógyászati Klinika és Kardiológiai Központ, Szeged

Levelezési cím: Dr. Komócsi András, komocsi.andras@pte.hu

Krónikus totális okklúziók (СTO) revaszkularizációja napjainkban is komoly kihívást jelent az intervenciós kardiológiában. A CTO-k megnyitásával jelentősen javulhat a beteg életminősége, javulhat a balkamra-funkció, valamint csökkenhet a mortalitás egyaránt. A megfelelően előkészített beteg, valamint a kellőképpen megtervezett intervenció nagyban befolyásolja a beavatkozás kimenetelét. Jelen esetbemutatásunkban egy korábban CABG-mütéten átesett, diabétesz, hipertónia, COPD miatt gondozott 52 éves betegünk jobb koronária (RCA) CTO megnyitását ismertetjük. A beavatkozást MR viabilitás vizsgálat előzte meg, alátámasztva az inferior, inferolaterális szegmentumok életképességét. Tekintettel a bal rendszer felöli, megfelelő epikardiális, vagy szeptális heterokollaterális hiányára, az RCA proximális szegmentumából eredő, jelentős kaliberủ homokollaterálison keresztül végeztük el a CTO retrográd megnyitását transzfemorális behatolásból. Jelen esetünkkel szeretnénk ismertetni a komplex CTO-intervenciók tervezésének, így a behatolási kapu, a vezetőkatéter-választás, a donor artéria, valamint az eszközök kiválasztásának szempontjait és bemutatni a CTO-megnyitás fö lépéseit.

Kulcsszavak: stabil angina pectoris, krónikus teljes elzáródás, PTCA

\section{Recanalisation of a right coronary СTO using retrograde approach via homocoronary collateral}

Transcatheter revascularization of chronic total coronary occlusions (CTO) remains a challenging field of interventional cardiology. Successful recanalization may improve ventricular function, quality of life, and may decrease mortality. Careful patient preparation and advance planning of the intervention is inevitable in order to improve the success rate of the procedure.

We present coronary intervention of a patient with history of diabetes, hypertension, chronic obstructive pulmonary disease and an earlier coronary bypass operation. Before the recanalization of the CTO of the right coronary artery, viability of the inferior, inferolateral segments of the left ventricle was verified with magnetic resonance imaging. With the absence of transseptal or epicardial heterocoronary collaterals the retrograde СТО recanalization was performed through the proximal homocoronary collateral. We would like to present this case to demonstrate the main planning steps of СТО interventions including access site, guiding catheter, donor artery and interventional tool selection and present the main steps of the intervention.

Keywords: stable angina pectoris, chronic total occlusion, PTCA

\section{Esetismertetés}

52 éves betegünk kórelőzményében ismert, magas vérnyomás, 2-es típusú diabetes mellitus miatti per os antidiabetikummal történő kezelés, valamint COPD szere- pelt. 2006-ban 3-as koronária bypassmütéten esett át (LIMA - LAD, SVG - CxOM, SVG - RCA). Kilenc évvel a mütétet követően CCS 3. intenzitású effort angina jelentkezése miatt noninvazív kivizsgáláson esett át. Echokardiográfián mérsékelt balkamra-hipertrófia 

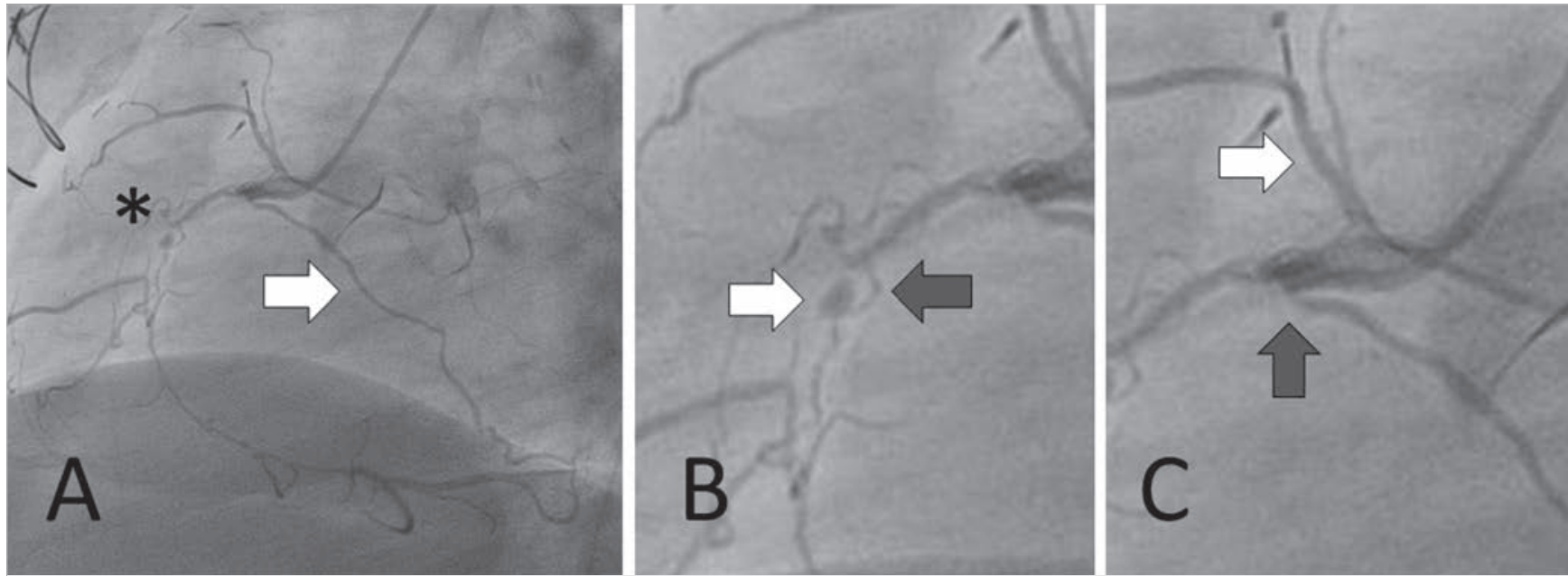

1. ÁBRA. A jobb koronária elzáródása. A: 60 LAO-nézet 5 Fr JR4 katéter. A csillag jelzi az elzáródás helyét, a nyíl a jelentős lumenú homokoronáriás kollaterálist. B: Az RCA elzáródása a gracilis áthidaló kollaterálissal (szürke nyíl) és annak aneurizmaszerū tágulatával (fehér nyíl). C: Az RCA eredési régiója a horgonyzásra korlátozottan alkalmas konális ággal (fehér nyíl) és a homokoronáriás kollaterális éles szögű eredésével (szürke nyíl)

ábrázolódott megtartott bal kamrai ejekciós frakció és ép billentyük mellett. Ergometrián 175 W (7 MET) terhelés mellett szignifikáns ST-depresszió provokálódott, SPECT-vizsgálata tranziens poszterior, poszterobazális iszkémiát igazolt. Koronária-angiográfián a vénás graftok elzáródása mellett jól vezető mammaria graft igazolódott, ami jól töltötte a jelentős, graftfüggővé vált LAD-rendszert. A jobb koronária krónikus elzáródása, valamint a jobb koronáriához vezető vénás graft csonk morfológiája miatt a vénás graft megnyitására történt rövid kísérlet, azonban ez sikertelen maradt. Az RCA ellátási területének viabilitás vizsgálatára MRI-vizsgálat történt, amely nem észlelt késői kontrasztanyag-halmozást, az inferior-inferolaterális terület 100\%-os életképességét igazolta. Az ezt követő anterográd CTO-megnyitási kísérlet sikertelen maradt. A bal rendszer vizsgálata során számottevő retrográd epikardiális vagy szeptális kollaterális nem ábrázolódott. A jobb koronária elzáródása proximálisan, az 1 . és 2 . szegmentum között szakaszon helyezkedett el (1. ábra). Az elzáródás mellett kis átmérőjü, áthidaló kollaterális ábrázolódott, középső szakaszán kis aneurizmával, valamint egy jelentős homokoronáriás kollaterális, amely az RCA proximális szakaszától a poszterolaterális ághoz futva az RCA intenzív (Rentrop II.) retrográd telődését biztosítja. Második ülésben tervezetten került sor a komplex CTO-megnyitásra.

\section{RCA CTO megnyitási intervenció}

Jobb transzfemorális punkciót követően, az RCA $8 \mathrm{Fr}$ AL1 katéterrel történő kanülálását végeztük. $A$ homokoronáriás kollaterálisba egy kompozit magszerkezetủ, polimer hegy és PTFE dróttest borítású Sion Black vezetődrótot és egy FineCross mikrokatétert vezettünk. A drótot a jobb kamrai ágba pozícionáltuk. A proximális elzáródási sapkában egy hidrofil polimer borítású, kúpos hegykiképzésü Fielder XT, majd egy mikrokúpos hegyü PTFE-borítású Gaia $2^{\text {nd }}$ vezetődróttal tudtunk előrehaladni. Annak ellenére, hogy az elzáródott RCA struktúráját a drót nem hagyta el, az a disztális szakasz magasságában nem jutott a valódi lumenbe, azzal párhuzamosan szubintimálisan haladt tovább. A retrográd megközelítésre áttérve a Finecross mikrokatétert a disztális elzáródási sapka közelébe vezettük és a disztális sapkát egy Miracle Bros hidrofób nem polimer borítású dróttal pungáltuk majd egy Gaia $2^{\text {nd }}$ vezetődróttal jutottunk az 1. és 2. szegmentum határához. Mivel a retrográd drót sem jutott az eredeti lumenbe, a két drót párhuzamos futásának területén az anterográd Gaia $2^{\text {nd }}$-re vezetett Ryujin Plus $2,5 \times 20 \mathrm{~mm}$ ballonnal végeztünk tágítást („fordított CART" manőver; Controlled Antegrade Retrograde subintimal Tracking) a 3. ballonfelfújást követően a retrográd Gaia $2^{\text {nd }}$ a proximális RCA-lumenbe jutott és azt, valamint a Finecross mikrokatétert a vezetőkatéterbe tudtuk juttatni. Az anterográd rendszer eltávolítását követően a Gaia $2^{\text {nd }}$ drótot egy 3,3 méter hosszúságú RG3 drótra cseréljük, amit előrevezetve externalizáltunk. Az externalizált vezetődrót-szakaszt felhasználva a jobb koronária oszlásáig Ryujin Plus $2,5 \times 20$ mm ballonnal elötágításokat végeztünk majd az eredés felé haladva az RCA törzsét 3 db sirolimus kibocsátó Orsiro stenttel támasztottuk meg (2. ábra).

\section{Megbeszélés}

Az intervencionális kardiológiai eszközök és eljárások fejlődésének köszönhetően egyre komplexebb léziók ellátására nyílik lehetőség. A krónikus koronária-elzáródások intervencionáis eljárásokkal történő rekanalizációja a szívkatéterezés egyik fontos kihívását képezi. Számos speciális eszköz és módszer került kifejlesztés- 


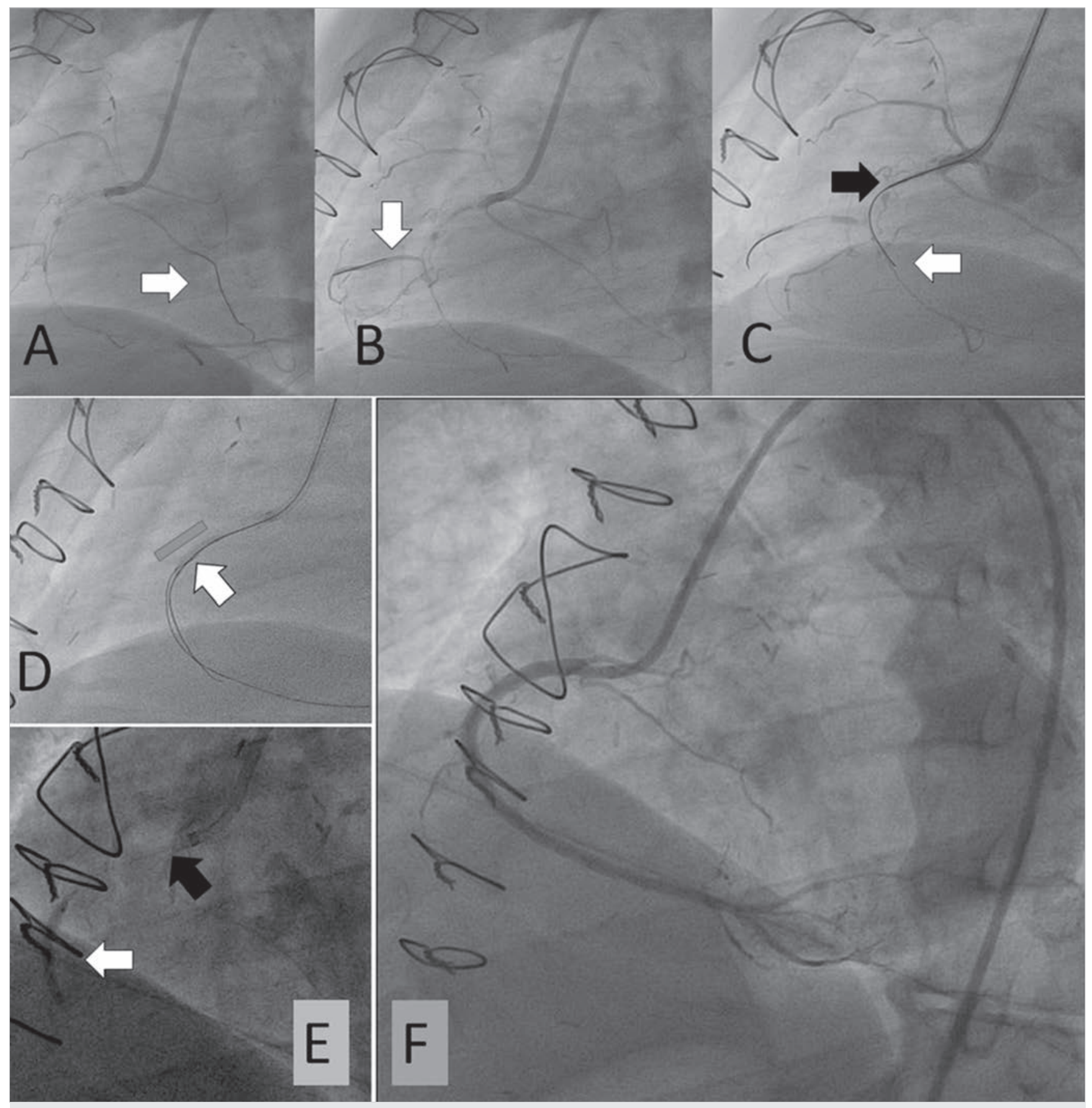

2. ÁBRA. A jobb koronária elzáródásának megnyitása. A: Markerdrót (nyíl) és mikrokatéter levezetése a kollaterális ágon. B: a markerdrót a jobb koronária akut marginális ágába pozicionálása (nyíl). C: Anterográd sapka punkciója, amit követően az anterográd drót szubintimálisan halad előre. D: A disztális sapka punkcióját követően a retrográd drót is szubintimális pozícióban halad elöre. A két drót közötti szakaszon végzett ballontágítást (a téglalap vetületében) követően a retrográd drótot (nyíl) a valódi proximális lumenbe tudjuk vezetni. E: A retrográd drótot a katéterbe vezetve és ezen a mikrokatétert szintén a katéterlumenbe juttatva az eredeti drótot egy $330 \mathrm{~cm}$ drótra cseréljük, amit a vezetőkatéteren keresztül ismét externalizálunk. A katéteren keresztül kijuttatott drótszár (fekete nyíl) segítségével anterográd komplettálható az intervenció ballon dilatációkkal, illetve stent-implantációkkal. F: A stentek implantációját követően készült felvétel

re, amelyek jellemzően az elzáródás anterográd megnyitását célozták meg, azonban ezek eredményessége az elvárttól elmaradt. Az 1990-ben publikálták amerikai szerzők a koronária kollaterálisokon történő megközelítés kivitelezhetőségét nonokklúzív léziók esetében, míg a krónikus elzáródások retrográd, szeptális kollaterálisokon keresztül történő megnyitását Surmely és munkatársai 2007-ben közölték (1, 2). Az elmúlt 10 évben a retrográd CTO-rekanalizáció a krónikus elzáródások megnyitásának eszköztárába beépült (3). 
Mint a stabil koronária-léziókkal kapcsolatos intervenciók esetében általánosságban, a krónikus elzáródások megnyitásának is a célja az iszkémiával kapcsolatos tünetek javítása. Ezért a panaszok hátterében álló iszkémia és az elzáródott ér ellátási területének életképessége a CTO-intervenciók tervezésének egyik alapfeltétele. A viabilitás megítélésére számos noninvazív módszer alkalmazható. Ezek közül a kontrasztanyagos MR-vizsgálatok kiemelkednek magas szenzitivitásukkal és reprodukálhatóságukkal. A nekrózis transzmurális kiterjedésének pontos meghatározása miatt intézetünkben ezt a módszert használjuk rutinszerűen a CTO-intervenciók tervezése során $(4,5)$.

A bemutatott eset intervenciós megoldásának tervezése során több, a beteg koronária-anatómiája által befolyásolt szempont figyelembe vételére volt szükség. A krónikus koronária-elzáródások megnyitásának egyik igen fontos szempontja az elzáródástól disztálisan elhelyezkedő szakasz megfelelő vizualizációja, a célrégióba történő navigáció biztosítása. A bemutatott esetben a jobb koronária disztális szakaszának telődése két úton volt biztosított. Ezek közül a kis átmérőjü, áthidaló kollaterális az elzáródás proximális sapkájának területén történő manipuláció és ballontágítások kapcsán veszélyeztetett, ennek az intervenció során történő elzárása várható. A proximális eredésű homokollaterális a jobb koronária kanülálását követően adott anterográd kontrasztanyag-injekciók kapcsán megfelelő festődést biztosított, azonban az intervenció során használt nagyobb átmérőjű vezetőkatéterrel végzett, szokásosan alkalmazott mélyebb kanülálás mellett, a kollaterális proximális, éles szögü eredése miatt ez nem feltétlenül marad elég intenzív az anterográd megnyitási kísérlet navigálásának biztosításához. Emiatt a kollaterálison levezetett vezetődrót és mikrokatéter rendszert markerként használva terveztük a célszakasz vizualizációját. A CTO megnyitási intervenciók során fokozott szerepet játszik a katéterrendszer által biztosított támaszték optimalizálása. Ezt a behatolási hely, a katéterméret és görbületválasztás által meghatározott passzív, mind a további manipulációkkal elérhető aktív támaszték formájában tudjuk elérni. Az aktív támasztékra gyakran alkalmazott manőver a horgonyzás, amit egy kisebb oldalágba történő drót- és ballonrendszer felvezetésével kivitelezünk. Esetünkben, a jobb koronáriával együtt, eredése mellett elhelyezkedő konális ágban ez optimálisan nem volt kivitelezhető, mivel ez az orificium elé horgonyozná le a katétert. Ebben az esetben nem biztosított a katéter intubált pozíciójának fenntartása, ezért esetünkben anatómia szituációja a horgonyzással történő passzív támaszték nem volt alkalmazható. Ezzel szemben a homokoronáriás kollaterálison vezetődrót-mikrokatéter rendszer várhatóan stabil katéter pozíciót biztosít.

A retrográd CTO-megnyitási manipulációk végzéséhez általában szimultán anterográd és retrográd vezetődrót-mikrokatéter rendszer levezetése szükséges. Ez heterokoronáriás kollaterálisok esetén kettős artériás behatolási kapu készítésével és a két koronária szimultán kanülálásával kivitelezhető. Kettős kanülálás használata esetünkben is felmerült, amely során a manipulációk az anterográd és retrográd rendszerrel felváltva (ún. ping-pong kanülálás formájában) történhet. A stabilabb passzív támaszték elérése miatt azonban inkább a nagylumenü közös vezetőkatéterben történő levezetést választottuk.

Irodalom

1. Kahn JK, Hartzler GO. Retrograde coronary angioplasty of isolated arterial segments through saphenous vein bypass grafts. Cathet Cardiovasc Diagn 1990; 20(2): 88-93. DOI: 10.1002 ccd.1810200205

2. Surmely JF, Katoh O, Tsuchikane E, Nasu K, Suzuki T. Coronary septal collaterals as an access for the retrograde approach in the percutaneous treatment of coronary chronic total occlusions. Catheter Cardiovasc Interv 2007; 69(6): 826-832. DOI:10.1002/ccd.20816 3. Ungi I, Tajti P, Hausinger $P$, Katona A, Sasi V, Thury A. The retrograde approach to coronary chronic total occlusion interventions. 1st ed. Hellenic College of Cardiology; 2015. p. 10-18. DOI: 10.10021 cce2.3

4. Windecker S, Kolh P, Alfonso F, Collet JP, Cremer J, Falk V, Filippatos G, Hamm C, Head SJ, Juni P, Kappetein AP, Kastrati A, Knuuti J, Landmesser U, Laufer G, Neumann FJ, Richter DJ, Schauerte P, Sousa UM, Stefanini GG, Taggart DP, Torracca L, Valgimigli M Wijns W, Witkowski A. 2014 ESC/EACTS Guidelines on myocardial revascularization: The Task Force on Myocardial Revascularization of the European Society of Cardiology (ESC) and the European Association for Cardio-Thoracic Surgery (EACTS)Developed with the special contribution of the European Association of Percutaneous Cardiovascular Interventions (EAPCI). Eur Heart J 2014; 35(37): 2541-2619. DOI: 10.1093/eurheartj/ehu278.

5. Di Mario C, Werner GS, Sianos G, Galassi AR, Buttner J, Dudek D, Chevalier B, Lefevre T, Schofer J, Koolen J, Sievert H, Reimers B, Fajadet J, Colombo A, Gershlick A, Serruys PW, Reifart N. European perspective in the recanalisation of Chronic Total Occlusions (СТO): consensus document from the EuroCTO Club. Euro Intervention 2007; 3(1): 30-43 